\title{
Investigation and Analysis of English ESP and EOP Teaching in Higher Vocational Colleges
}

\author{
Zujun Chen \\ Xi'an Peihua University, Xi’an, 710100, China
}

Keywords: vocational college, English teaching, ESP, EOP

\begin{abstract}
In the era of economic globalization, China, as a member of WTO, has become an extremely important participant in international economic and trade relations. China's foreign economic exchanges have become increasingly frequent. In the past, universities have cultivated a single foreign language or single skill of students, which has been unable to adapt to the needs of economic and social development. In order to adapt to the current market demand, to enable students to adapt to market development, vocational colleges offer ESP (English for Specific Purposes, specialized use of English) and more detailed EOP (English for Occupational Purposes), which is imperative, but also the future direction of English teaching.
\end{abstract}

\section{Introduction}

English for Specific Purposes (ESP), refers to English courses related to a specific occupation or discipline, such as medical English, legal English, travel English, financial English, academic English, science and technology English. The goal of the course is to develop students' ability to use English to work in a given working environment. The ESP course requires content related to a particular occupation, and its vocabulary, syntax, and discourse are applied to the language of a particular professional, career-related activity. ESP English can also be based on different purposes derived EAP (English for Academic Purposes, academic English) and EOP (English for Occupational Purposes, industry English). Based on the characteristics of students' students and the future job requirements, this paper discusses the current situation and development of ESP and EOP in English teaching in Higher Vocational colleges.

\section{The Concept and Significance of English ESP and EOP in Higher Vocational Colleges}

ESP is usually a combination of specific work or industry-specific content related to generally effective communication skills. ESP has two obvious characteristics: First, learners have a clear purpose, and ESP course can be applied to specific areas of occupation; the second is that ESP course has a special content, which is related to the professional knowledge related to the specific field. In short, ESP (English for Specific Purposes) is an applied English course which is the combination of English basic skills and professional knowledge and skills. According to the purpose of the learner's language used finally, ESP has two branches: English for Academic Purposes (EAP) and English for Occupational Purposes (EOP). The goal of EOP is to develop English communication skills of students in a specific working environment. EOP model teaching is based on professional requirements, start from the job requirements of students, teach through career scenarios reproducing, cultivate students' professional ability and achieve professional courses combined perfectly with professional positions.

In the context of economic globalization, the exchanges between the various fields of the world are becoming increasingly widespread, and more and more people need not only to master English, but also have the ability to use English in related fields. There are two main types in English educational system in our country: Basic English or EGP (English for General Purpose), and English for Specific Purpose(ESP). Basic English teaching emphasizes the basic language knowledge of English, including vocabulary and grammar, but mastering the basic English is still 
far from being able to meet the need to deal with work in specific field, Because of the reason above, specialized use of English should be highlighted. The traditional basic English teaching system emphasizes the basic language knowledge and skills of the students, which can not meet the needs of the society which needs people not only to know English but also to master the professional knowledge. Considering the development of the times, the reform of English teaching has new challenges. The demand for diversified and specialized English talents is imperative. Specialized English teaching is the combination of English knowledge and professional knowledge to meet the practical needs of learners. It focuses on the learner's practical language application ability and it is meaningful to the current English curriculum reform.

\section{The Present Situation of ESP and EOP Teaching in Higher Vocational Colleges}

The Background of Public English Reform in Higher Vocational Education

Higher vocational education personnel training is based on higher vocational colleges' purpose of running a school "to serve the local industry, to combine with the occupation, to be based on the work process." ESP occupies an important position in English teaching and it will be an important trend in the future teaching, and the combination of profession requirements and EOP English will become the mainstream and direction of public English teaching.

At present, EGP(English for General Purpose) English teaching in vocational colleges is too long and inefficient. EGP teaching goal is to train students to have a certain listening, speaking and reading skills, which is so broad and fuzzy. Some colleges have offered professional English courses in the third and fourth semesters for students of some majors. A considerable number of students are eager to have a transitional course between basic English and professional English or bilingual courses. But meanwhile some colleges have never set up professional English courses. Based on this, it is more necessary to have ESP teaching which is used to increase the unawareness of professional background, to improve their English ability closely related to one's profession with the help of competent language teachers. For students of higher vocational colleges, it is EOP, the ideal course, that can cultivate this ability to improve the English proficiency of the industry and to work directly in English.

Students do not have access to real English skills that are combined with their own professions during school, wasting valuable learning time and resources. If there is no specialized field or specific industry English ability, only the general English comprehensive application ability, it is difficult to adapt to the economic integration of all walks of life international talent requirements. EOP teaching emphasizes that teaching content should work on the basis of the job task, organizing teaching in real work environment or simulated occupational situation. Change EGP, which just cultivate students' simple language learning skills, to EOP, which is closely related with industry needs, thus enabling students to have future job competitiveness, to communicate with language English, to get information in English and work in English.

\section{The Implementation and Analysis of ESP and EOP Teaching in Higher Vocational Colleges}

The ESP teaching, which links high school English, is characterized by the general English of one's daily life, and the vocational English should not only be used to improve the general listening and speaking ability. English learning is no longer only to learn general language skills, but increasingly to learn a combination of certain aspect of professional knowledge and discipline, and English which special job requires is far from achievable only by basic English teaching. The learning foundation and foreign language level are so different between the higher vocational college students and university students. Therefore, for higher vocational college students with just the common EGP language level, there are some difficulties or incompatibility. And EOP English courses will be able to make up for these deficiencies. In addition, vocational colleges are training students' occupational skills and applied abilities, which allows students first to learn the knowledge and skills and then apply it into practice and work right away. The lack of vocational English application ability is a bottleneck restricting the sustainable development of students' career in the 
future. Therefore, the shift of Public English from EAP to EOP is the key to the reform of public English teaching, and it will also be the way to the future of public English teaching.

EOP teaching is the implementation of English to the professional field, fulfillment of oral and written communication of students in specific work field, which aims to train students to master listening, speaking, reading and writing skills based on job needs of the industry, and it is productive-an output of the language. Due to the limited English level of vocational students, when they face too many boring, uncommon professional vocabulary, obscure professional theoretical knowledge combined with professional English by grammar-translation teaching mode, high vocational college students feel difficult to learn, and there is burnout in professional English learning. The EOP course is a bilingual course or a transitional course towards professional English, which is a work scene in English to string together, which is close to the target scene, which has the intuitive context, which is relatively simple and practical, which has clear job objectives, and which makes students to accept it more easily .

Higher vocational EOP teaching materials are written in different forms from the professional English textbooks. Bilingual or English professional English belongs to a professional teaching category. But the ultimate goal of EOP course is to develop students ability to use English in a specific working environment, to complete a working process, and to complete the task of the corresponding position. EOP focuses on the construction of a reasonable industry work structure, and the language covers vocabulary, syntax, discourse, grammar, register, style etc used in specific activities of the industry. EOP requires teaching materials to highlight the job needs, and the materials should be practical and operational.

Some scholars have suggested that the future of language teachers should develop a special era of ESP, but some of the higher vocational English teachers are content with the existing EGP teaching materials, and they rigidly adhere to the traditional evaluation methods, do not want to accept the challenge, and dare not try EOP teaching. In fact, as the branch of ESP, EOP does not require a high level of knowledge about the teacher's background, so language teachers are fully competent. EGP teachers should change their existing thinking of EGP, and establish the EOP teaching concept, make full use of valuable public English teaching resources, and truly change the current time-consuming and inefficient situation of public English teaching in higher vocational colleges from the demand of learners' target positions. EGP teachers should pay attention to professional self-development, establish a professional level of industry English teacher team, familiar with the industry language, to participate in professional training, and develop EOP teaching materials with professional teachers and business people. Besides, they can exchange EOP teaching reforms with professional teachers, encourage language teachers to apply for industry English qualification examination, and promote the improvement of industry English quality through continuous learning and self-reflection.

\section{Conclusion}

All in all, the simple EGP teaching has been unable to meet the needs for complex talents of today's society, so ESP and EOP teaching should be vigorously promoted. It is not only to meet the needs of social development, but also to meet the inherent needs of vocational education to cultivate skilled personnel. By promoting the development of ESP and EOP in vocational English teaching, we will cultivate more complex foreign language talents with practical English skills and practical skills to meet the needs of social talents.

\section{References}

[1]Qingfen Ji, Application of EGP + EOP Model in Higher Vocational English Teaching, Journal of Qingdao Ocean-going Seafarer Vocational College,33(4), pp.75-78, 2012.

[2]Xinzhu Peng, Study on EOP Teaching in Higher Vocational Colleges, Journal of Educaitonal Institute of Jilin Province, 430(32), pp.82-82, 2016. 
[3]Hong Zhao, On the Shift of Public English Teaching to EOP in Higher Vocational Colleges, New Curriculum Research,15(1), pp.67-69, 2015.

[4]Liang Jin, Research on the Shift of EOP Teaching Mode in Higher Vocational Education Based on Job Demand Analysis, Journal of Educational Institute of Jilin Province, 386(31), pp.109-110, 2015. 